\title{
СТИЛІСТИЧНІ ФУНКЦІЇ АНГЛІЗМІВ РІЗНИХ СЕМАНТИЧНИХ ГРУП У ТЕКСТАХ ІНФОРМАЦІЙНОГО СТИЛЮ
}

Майструк Т. С. Стилістичні функції англізмів різних семантичних груп у текстах інформаційного стилю.

У статті йдеться про вживання стилістично забарвленої англійської лексики в текстах інформаційного стилю, визначаються найчастотніші семантичні групи узуальних англізмів та функціонально-прагматичний потенціал. Оказіональні англізми розглядаються як особливий різновид запозичень, які характеризуються більшим експресивним потенціалом, ніж узуальні лексеми, і мають великий вплив на культуру мовлення.

Ключові слова: інформаційні тексти, узуальні англійські запозичення, оказіональні англізми, стилістичні функції.

Майструк Т. С. Стилистические функции англизмов разных семантических групп в текстах информационного стиля.

В статье рассматривается использование стилистически окрашенной английской лексики в текстах информационного стиля, определяются наиболее часто используемые семантические группы узуальных англизмов и их функционально-прагматический потенциал. Окказиональные англизмы рассматриваются как особый вид заимствований, которые характеризуются большим экспрессивным потенциалом, чем узуальные лексемы, и имеют большое влияние на культуру речи.

Ключевые слова: информационные тексты, узуальные английские заимствования, окказиональные англизмы, стилистические функции.

Maystruk T. S. The stylistic functions of anglisms of different semantic groups in the texts of informational style.

The article presents the using of stylistic-colored English vocabulary in the texts of informational style, the most frequent semantic groups of uzual anglisms and their functionalpragmatic potential are also determined. Okkazional anglisms are considered as a special type of borrowings, which are characterized by larger expressive potential than uzual ones, and which have a great influence on the culture of speech.

Key words: the informational texts, uzual English borrowings, okkazional anglisms, stylistic function.

Незважаючи на велику кількість праць, присвячених англійським запозиченням, недостатньо розкритими залишаються питання стилістичних функцій англізмів. Так, науковці намагалися дати загальну характеристику англійським запозиченням (О. Дьолог, І. Каминін, О. Зеленін), розглядали їх семантичні групи (М. Агапоненко, В. Сінгалевич, Н. Попова), доцільність використання та вплив на культуру мови (М. Каранська, Т. Зогоруйко, I. Фаріон, Т. Кияк, Г. Шаповалова). Були також спроби розглядати функціонування англізмів, однак це робилося лише з точки зору їх уживання (С. Форманова, Т. Журова, М. Кириленко), поза увагою залишалася сама специфіка функціонування, тобто роль англізмів в українській мові.

Мета нашої статті полягає в тому, щоб визначити особливості реалізації стилістичних функцій англізмів різних семантичних груп в інформаційних текстах. 
Як відомо, метою текстів інформаційного стилю є інформування широких мас населення про суспільно важливі події, однак, це не значить, що такі тексти позбавлені стилістично забарвленої лексики. Більше того, стилістичне забарвлення англійських запозичень в інформаційних текстах виявляється в основному яскравіше, ніж, скажімо, у текстах публіцистичного стилю. Щоб інформація була доступною та зрозумілою адресату, у текстах інформаційного стилю, як правило, використовується загальновживана питома лексика, спеціальна термінологія, яскравість лексики різної тематики вводиться в рамки окремих жанрів, тому більшість англізмів, представлених у цих текстах, має яскраво виражений експресивний потенціал.

Крім того, основна функція англізмів в інформаційних текстах - оцінна. Більшості англізмів притаманна оцінна конотація, яка передає узуально-закріплене негативне ставлення до денотата. В основному це англійські запозичення семантичної групи „Культура”, які побутують у текстах суспільної тематики. Наприклад: Сьогодні о 19.00 в Національному палащі „, Украйна” відбудеться конщерт італійської поп-групи „,Матіа Базар”. Ціна квитків - від 70 до 500 гривень. Навіть у 70-х роках, коли радянська молодь мліла від любові до солодкої італійської попси (i не була винятком у цьвому сенсі в Свропі), „Матіа Базар” виділялася на загальному тлі „італійщини" вокальною вишуканістю, складністю мелодій та аранжувань своїх пісень („Україна молода”, № 239, 22.12.06). Так, спочатку запозичилося англійське слово non (скорочено від англ. pop(ular) - народний, популярний; загальнодоступний) на позначення першої частини складних слів, що означає „масовий”, „популярний”. Пізніше воно набуло українських афіксів і вживається зі зниженим значенням, адже поnca - це знижене позначення проявів масової культури $[2,438]$; виконує оцінну функцію - передає негативне ставлення до висловлюваного.

Наступний англізм має експресивну конотацію: Справжній „екшн” розігрався близько третьої ночі на одній із зупинок громадського транспорту в Дарницькому районі Кисва. Як повідомили «УМ» у Центрі громадських зв'язків столичної міліиії, саме в цей час до Дарницького райуправління мілічї надійшло повідомлення про автоматні черги, які порушили нічну тишу („Україна молода”, № 188, 8.10.08). Так, англізм екшн (англ. асtion - бурхлива діяльність; бойові дії), що належить до семантичної групи „Культура”, тлумачиться як жанри сучасних пригодницьких літератури й кіно; творам цього типу властиві гострота сюжету, швидка зміна дій і становищ, у яких опиняються герої [7,259]. У зазначеному прикладі екшен означає стрілянину. Ознакою, на основі якої виникла співвіднесеність цих понять, є динамічність. Крім того, цей англізм виконує не лише експресивну, але й оцінну функцію, адже передає негативне ставлення автора до описуваних подій.

Велика кількість англійських запозичень уживається також у текстах політичного спрямування. 3 метою змалювання негативного ставлення ав- 
тора до політичних осіб використовується такий стилістичний прийом, як іронія, до того ж іронія відкрита, адже сам оповідач акцентує на цьому увагу: Відпрацювавши своє в гарячі днини виборів у жанрі , чорного гумору" під гаслом: ми кепкуємо з усіх кандидатів, крім головного - оскільки він не кандидат, він чинний Президент - Кирило тепер перейшов до легшої вагової категорії-чорної іронії. Щоправда, і для іронії у стилі „лайт”, як $i$ раніше, залишається ,, персоною нон грата” та ж головна фігура нашої політики (,День”, № 111, 23.06.00). Так, англізм лайт (англ. light) перекладається як легкий, незначний, легковажний $[1,196]$, у зазначеному прикладі йдеться про легку іронію, з якою автор ставиться до політичного діяча.

Дуже часто в інформаційних текстах суспільно-політичної тематики вживаються англізми, які є виразниками їдкої іронії, тобто іронія в інформаційних текстах часто переростає в сарказм. Такі англізми спрямовані на викриття несправедливості, жорстокості політичних діячів та суспільних явищ. Наприклад: Після того, як Палестинські бойовики в січні цзього року продемонстрували свої здібності з прориву кордону й організацї в сусідньому Сгипті безконтрольного „шопінгу”, Каїр спрямував зусилля на послаблення блокади анклаву (,Дзеркало тижня”, № 20, 26.05-1.06.01). Англізм шопінг означає відвідування магазину чи магазинів 3 метою купівлі чого-небудь; процес купівлі, закупівлі товарів [2, 614]. Очевидно, що сам англізм не має негативної конотації, однак йому присвоюється негативне забарвлення, адже під словом шопінг у поданому прикладі розуміється пограбування. Цей англізм виконує оцінну функцію, адже передає різке негативне ставлення автора до суспільних подій, а також є засобом експресії, оскільки питома лексема не змогла б надати висловлюванню такої образності та яскравості.

Іноді засобом сарказму виступають англізми, які мають негативну конотацію. Наприклад: 19 вересня у примімення Баранинцівської сільської ради увірвалася група людей у супроводі праиівників Ужсгородського райвідділу мілічії та підрозділу Державної виконавчої служби Головного управління юстиції в Закарпатській області. Непрохані гості виламали двері кількох кабінетів, захопили документи... Близько 19-ї години рейдери (а інакше їх назвати важко) вигнали працівників сільради на вулицюю, приміщення замкнули своїм замком („Сільські вісті”, № 121, 14.10.08). Так, peйдер (від англ. raider - нападник) у „Сучасному словнику іншомовних слів" за 2006 рік (уклад. Скопненко О., Цимбалюк Т.) тлумачиться як військовий корабель (крейсер, лінкор) або озброєне торговельне судно, що проводить самостійні бойові дії на морських комунікаціях [7, 587], проте в іншому словнику іншомовних слів за 2008 рік (уклад. Данилюк І.), окрім вищезазначеного, подається наступне визначення англізма рейдер це особа, агент, який здійснює фактичну купівлю (захоплення) підприємства всупереч бажанню його власників на користь зацікавлених осіб, які його найняли [8, 424]. Отже, досліджуваний англізм є неологізмом, адже від- 
булося переосмислення його значення. Як у попередніх двох прикладах, він виконує експресивну та оцінну функції - різка критика, саркастичне ставлення до описуваних осіб, їх засудження. Обурення та сарказм підсилюються уточненням, яке подається поряд у дужках.

Трапляються також поодинокі випадки вживання в інформаційних текстах суспільної тематики розмовних англізмів. Наприклад: До речі, доблесні українські „копи”, коли їх викликали на місие події побиті жінки, як завжди, стояли осторонь $i$ не втручалися в процес побиття - мабуть, тихо сподіваючись, що бандюки зрештою впораються з людьми самотужки („Народне слово”, вип. за 22.10.08). Так, коп, що значить „поліцай” [1, 78], є розмовною лексемою, небажаною в текстах інформаційного стилю, однак його вживання можна виправдати, якщо воно виконує стилістичні функції (див. наведений приклад). Спочатку цей англізм увійшов в українську мову як екзотизм, потім набув негативного стилістичного забарвлення, характеризуючи поліцейських у негативному плані. Як і аналізовані вище англійські запозичення, слово коп є експресивним та передає високий рівень автора у володінні культурою мовлення, адже він зумів влучно використати небажаний англізм, який в іншому контексті міг стати виявом неосвіченості. Це є доказом свідомого використання автором цієї лексеми.

Не менш важливими в текстах суспільно-політичної тематики $є$ також англізми-метафори, які, окрім оцінної, виконують ще дескриптивну функцію. Метафорами стають ті англійські запозичення, які переносяться у сферу політики з інших сфер діяльності. До таких англізмів слід віднести інтернаціональні лексеми спортивної тематики (cmapm, maйм, матч, peфері, пінг-понг). Наприклад: - Як ви гадаєте, чи зміниться після виборів ставлення Росії до пострадянських республік? - На жаль, ні. Ti, хто перебував у фарватері Росії, там і залишаться. До більш незалежних України, Грузії та Молдови ставлення залишиться тим самим. Ці країни перебувають у так званому чорному списку Кремля. Але поки зіграно лише перший тайм. Матч завершиться в березні, коли відбудуться президентські вибори („День”, № 211, 4.12.07); Мінфін запевняє: у державному бюджеті на 2007 рік на виплату допомоги при народженні дитини враховано 3,9 мільярда гривень, щьо на 400 мільйонів гривень більще, ніж у поточному рочі. Насправді останніми днями в інформаційному просторі Украйни відбувається справжній економічно-політичний пінг-понг: урядовиі „видають” свої наміри на-гора, а після хвилі критики на свою адресу починають спростовувати свої ж повідомлення („Україна молода”, № 172, 20.09.06).

Окрім метафори, у наведених прикладах використано ще такий стилістичний прийом, як іронія, адже пінг-понг - це назва спортивної гри, тайм та матч - складові спортивної гри, тобто принцип спортивної гри переноситься в політику. У результаті цього нейтральні інтернаціональні англомовні лексеми набувають стилістичного забарвлення, вони виражають іронічне ставлення автора до висловлюваного. Крім того, ці англізми викону- 
ють ще експресивну функцію, адже вони надають висловлюванню образності та незвичності. Уживання інтернаціональних англізмів семантичної групи „Спорт” у текстах політичної тематики є досить поширеним явищем, однак не випадковим. 3 цього приводу А. Коваль зазначає, що серед міжстильових засобів української мови особливої уваги заслуговують іншомовні інтернаціоналізми, адже „наявність їх у кількох неспоріднених мовах створює можливість - у разі потреби - передавати певні додаткові семантико-стилістичні нюанси" [5, 61]. Цими нюансами є те, що автори інформаційних текстів у такий спосіб порівнюють політику з грою, дають негативну характеристику політичним подіям та особам.

Окрім загальномовних (узуальних) англізмів, у текстах інформаційного стилю є певна кількість індивідуально-авторських (оказіональних) англійських запозичень. Оказіональні англізми є досить специфічним явищем 3 погляду стилістики, адже вони мають більший експресивний потенціал, ніж узуальні лексеми, а також „породжують безліч асоціацій у зв’язку 3 актуалізацією периферійних сем, що значно розширює семантику лексичної одиниці, вводить іiі у стихію нових значень" [3, 17]. Оказіональні англізми характеризуються новизною, незвичністю, несподіваністю поєднання 3 іншими лексемами, вони ілюструють виключно суб'єктивне світобачення i світосприйняття автора, отже, виконують характерологічну функцію. Слушну думку висловлює Н. Бойко про те, що стилістичне значення неологізмів-оказіоналізмів „грунтується не лише на емотивному та оцінному компонентах значення, а й на таких додаткових ознаках, як специфічність і ненормативність, функціональна обмеженість, зв'язок з контекстом. Через призму цих ознак сприймаються найтонші нюанси оказіоналізмів” [3, 16].

В інформаційних текстах створено сприятливі умови для виникнення оказіональних англізмів, оскільки „мова газетного стилю швидко реагує на процеси суспільного життя, а багатство їі внутрішніх ресурсів дозволяє словесно відобразити широку гаму відтінків значення нових реалій позамовного світу" $[6,88]$. Оказіональні англійські запозичення є дуже яскравими, експресивними i, як правило, виконують декілька стилістичних функцій. Наприклад: Зникли і їдальні громадського харчування: у проданих приміщеннях - кафе-бари та ресторани. Отож тут зникли й ці назви. Тепер маємо буйне засилля ,біг-мордів” з рекламою алкоголю. Тут - на всіх ,язиках”. Повний інтернаціонал. Всюди - латиниця, калькування 3 англійської, французької, іспанської - мірою володіння ними художниками-графописиями („Українське слово”, № 32, 10-16.08.05). Особливістю оказіональної лексеми біг-морда є те, що ії стилістичні функції слід розглядати на рівні словотвору, адже спочатку вона ввійшла в українську мову як словосполучення біг-борд (від англ. big board - дошка для рекламних оголошень). На основі дериваційних процесів від твірної основи біг утворилося нове слово, яке засвідчує незвичне поєднання нейтрального англізму та питомої лексеми, що належить до просторічної лексики і має негати- 
вну оцінну конотацію. Таке поєднання яскраво ілюструє іронічне ставлення мовця до висловлюваного. Однак стилістичне забарвлення цього оказіонального запозичення не обмежується лише іронією. Той факт, що автор перетворив стилістично нейтральну лексему біг-борд на згрубіле просторіччя біг-морда, дозволяє простежити емоції автора - роздратованість та пригнічення. Інша мета досліджуваного англізму - створити переконливий образ зображуваного предмета, дати йому негативну характеристику. Отже, оказіоналізм біг-морда виконує оцінну, емотивну, характерологічну та експресивну функції.

Англізми не завжди є позитивним явищем в українській мові. Це стосується тих випадків, коли в мові-реципієнті наявний питомий відповідник, але журналісти наполегливо користуються англомовною лексикою. На думку Г. Шаповалової, яку ми поділяємо, до використання англізмів журналістам варто підходити досить помірковано й виважено, адже зловживання такими словами засмічує мову, позбавляє іiі самобутності й природності [9, 124]. Наприклад: Паралельно Дуглас-джсуніор „набивав руку”, знявиись у кількох не надто відомих широкоекранних стрічках (,Україна молода", № 174, 22.09.06). Так, джуніор (англ. junior) в перекладі з англійської означає „молодший” $[1,187]$. Можливо, автор намагався в такий спосіб якомога більше наблизити українського читача до англійської реальності, однак досліджуваний англізм, на наш погляд, ускладнює розуміння тексту, він є недоречним, значить, порушує норми культури мови. Ми підтримуємо думку І. Голуб про те, що використання неологізмів у мовленні викликає великі труднощі, оскільки лексична, граматична, синтаксична i стилістична характеристики багатьох нових слів ще не визначилися. Звернення до оказіональних неологізмів завжди повинно бути стилістично мотивованим $[4,99]$.

Отже, в інформаційних текстах суспільно-політичної тематики узуальні англійські запозичення виконують переважно оцінну функцію. До них належать англізми семантичної групи „Культура”, „Економіка та фінанси” i „Суспільство”. Крім того, у політичних текстах деякі з цих англізмів дають негативну, викривальну характеристику політичним явищам та особам. Ця мета досягається шляхом використання такого стилістичного прийому, як іронія.

Велике значення для текстів інформаційного стилю мають оказіональні англізми. Вони виконують декілька функцій (оцінну, емотивну, експресивну, характерологічну), які накладаються одна на одну, відтак оказіональні неологічні англізми мають більший стилістичний потенціал, ніж узуальні лексеми.

Уживання оказіональних англізмів не завжди є мотивованим у текстах інформаційного стилю. Значення деяких із них є незрозумілим читачеві, вони порушують норми культури мови. Велика їх кількість може стати причиною втрати самобутності української мови. 


\section{Література}

1. Англо-украӥнський, украӥнсько-англійський словник [уклад. Н. М. Биховець, І. І. Борисенко, Г. О. Герасименко та ін.] / За ред. Ю. О. Жлуктечка. - К.: ВЦ „Академія”, 1997. - 696 с.

2. Бабик С. П., Сюта Г. М. Словник іншомовних слів: тлумачення, словотворення та слововживання / [ред. С. Я. Срмоленко]. - Харків : Фоліо, 2006. -623 с.

3. Бойко Н. I. Типи лексичної експресивності в українській літературній мові / Н. І. Бойко // Мовознавство. - 2002. - №2-3. - С. 10-21.

4. Голуб И. Б. Стилистика русского языка: Учеб. пособие для студ. вузов. - 3-е изд. - М.: Айрис-Пресс, 2002. - 448 с.

5. Коваль А. П. Практична стилістика сучасної української мови. - 2-е вид. - К.: Вища школа, $1978-375 \mathrm{c}$.

6. Коць T. А. Функціонування синонімів у газетно-інформаційному стилі (на матеріалі газет 90-х років XX ст.) / Т. А. Коць // Мовознавство. - 2001. - № 4. C. 88-95.

7. Сучасний словник іншомовних слів : Близько 20 тис. слів і словосполучень / [уклад. О. І. Скопненко, Т. В. Цимбалюк]. - К.: Довіра, 2006. - 789 с. - (Словники України).

8. Сучасний словник іншомовних слів для середньої і вищої школи: Близько 20000 слів [уклад. І. Г. Данилюк]. - Донецьк: Бао, 2008. - 576 с.

9. Шаповалова $Г$. Джерела сучасної неологічної лексики іншомовного походження та доцільність ії використання / Г. Шаповалова // Вісник Львівського університету. Серія „Журналістика”. - Львів, 2003. - Вип. 23. - С. 121-125. 